\title{
Profitabilitas, Operating Leverage, Ukuran Perusahaan Pertumbuhan Penjualan pada Struktur Modal Perusahaan Perbankan
}

\author{
Kadek Angga Sintya Puspita ${ }^{1}$ \\ Fakultas Ekonomi dan Bisnis \\ Universitas Udayana, Indonesia
}

\author{
Gede Juliarsa ${ }^{2}$ \\ Fakultas Ekonomi dan Bisnis \\ Universitas Udayana, Indonesia
}

Surel : anggasintya02@gmail.com

\section{ABSTRAK}

Penelitian ini dilakukan untuk mengetahui pengaruh Profitabilitas, Operating Leverage, Ukuran Perusahaan dan Pertumbuhan Penjualan pada Struktur Modal Perusahaan Perbankan. Penelitian ini menggunakan metode nonparticipant observation. Sampel yang digunakan sebanyak 23 perusahaaan dengan jumlah sampel amatan sebanyak 115 dalam 5 tahun, melalui metode nonprobability sampling dengan teknik purposive sampling, dan jumlah yang diperoleh sebanyak 115 obervasian. Teknik analisis data yang digunakan dalam penelitian ini adalah teknik analisis regresi linear berganda. Hasil penelitian ini menunjukkan bahwa profitabilitas berpengaruh negative pada struktur modal perbankan. Operating leverage berpengaruh negatif pada struktur modal perbankan. Ukuran perusahaan berpengaruh positif pada struktur modal perbankan. Pertumbuhan penjualan tidak berpengaruh pada struktur modal perbankan.

Kata Kunci: Profitabilitas; Operating Leverage; Ukuran Perusahaan; Pertumbuhan Penjualan.

\section{Profitability, Operating Leverage, Company Size, Sales Growth on the Banking Capital Structure}

\section{ABSTRACT}

This research was conducted to determine the effect of Profitability, Operating Leverage, Company Size and Sales Growth on the Capital Structure of Banking Companies. This research uses nonparticipant observation method. The sample used is 23 companies with a total sample of 115 observations in 5 years, through nonprobability sampling method with purposive sampling technique, and the number obtained is 115 observations. The data analysis technique used in this research is multiple linear regression analysis techniques. The results of this study indicate that profitability has a negative effect on the capital structure of banks. Operating leverage has a negative effect on the capital structure of banks. Firm size has a positive effect on banking capital structure. Sales growth has no effect on the banking capital structure.

Keywords: $\quad$ Profitability; Operating Leverage; Company Size; Sales Growth.

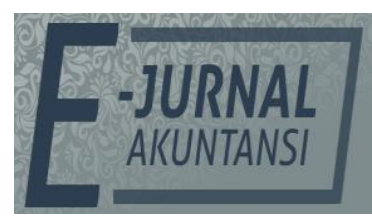

e-ISSN 2302-8556

Vol. 30 No. 12

Denpasar, Desember 2020

Hal. 3066-3080

DOI:

10.24843/EJA.2020.v30.i12.p06

PENGUTIPAN:

Puspita, K.A.S. \& Juliarsa, G. (2020). Profitabilitas, Operating Leverage, Ukuran

Perusahaan Pertumbuhan Penjualan pada Struktur Modal Perusahaan

Perbankan. E-Jurnal Akuntansi, 30(12), 3066-3080

RIWAYAT ARTIKEL: Artikel Masuk: 9 Juli 2020 Artikel Diterima: 8 Desember 2020

Artikel dapat diakses : https://ojs.unud.ac.id/index.php/Akuntansi/index 


\section{PENDAHULUAN}

Masalah struktur modal merupakan masalah penting bagi setiap perusahaan, karena baik buruknya struktur modal perusahaan akan mempunyai pengaruh langsung terhadap posisi keuangannya. Pentingnya penentuan struktur modal dikarenakan dapat menjadi pondasi yang kuat bagi perusahaan untuk menjalankan aktivitas produksinya, serta mampu mendapat keuntungan yang optimal bagi perusahaan (Nadzirah, et al., 2016). Struktur modal yang kuat sangat penting bagi sebuah bank, karena dengan struktur modal yang kuat bank akan bisa menghadapi persaingan global dan krisis ekonomi yang bisa terjadi sewaktu-waktu. Seperti fenomena yang terjadi saat krisis ekonomi pada tahun 1998. Dimana perdagangan global mengalami collapse sehingga bank enggan menyalurkan kredit untuk kegiatan yang berhubungan dengan ekspor.

Beberapa teori yang mendasari struktur modal perusahaan menurut Brigham (2010) yaitu Pecking Order Theory menyatakan bahwa, perusahaan lebih menyukai pendanaan dari hasil operasi perusahaan. Trade Off Theory yang menyatakan bahwa semakin besar perusahaan maka perusahaan dapat memakai utang lebih banyak terkait dengan rendahnya risiko perusahaan besar. Jumlah utang yang tinggi harus diimbangi dengan modal yang tinggi karena bank harus melindungi perusahaannya dari risiko ketidakpastian akan tingkat keuntungan yang didapat. Karena bisa saja terjadi penarikan dana nasabah secara besarbesaran dalam waktu yang bersamaan (rush). Bila hal itu tidak didukung oleh modal sendiri yang kuat maka likuiditas perusahaan akan menurun, yang akhirnya akan berdampak terhadap tidak mampunya bank dalam menyediakan dana yang dapat ditarik sewaktu-waktu oleh para deposan sehingga hal tersebut dapat menyebabkan bank gagal dalam beroperasi.

Salah satu faktor yang mempengaruhi struktur modal perusahaan adalah profitabilitas. Menurut Van Home (2007), profitabilitas adalah suatu hubungan yang terjadi antara laba dengan penjualan dan laba dengan investasi yang secara bersama-sama keduanya menunjukkan efektifitas keseluruhan operasi perusahaan. Menurut Kasmir (2010) profitabilitas merupakan rasio untuk menilai kemampuan perusahaan dalam mencari keuntungan dan juga memberikan ukuran tingkat efektifitas manajemen suatu perusahaan. Hal ini ditunjukkan oleh laba yang dihasilkan dari penjualan dan pendapatan investasi, intinya adalah bahwa rasio ini menunjukkan efisiensi perusahaan. Penelitian yang dilakukan oleh Dharmadi \& Putri (2018) menemukan bahwa profitabilitas berpengaruh positif terhadap struktur modal. Sedangkan penelitian yang dilakukan oleh Septiani \& Suaryana (2018), Andayani \& Suardana (2018) serta Gunadhi \& Putra (2019) menemukan bahwa profitabilitas berpengaruh negatif terhadap struktur modal.

Faktor lain yang mempengaruhi struktur modal yaitu operating leverage (OL). Salyo (1995) menyatakan operating leverage adalah pemanfaatan aktiva dengan menyertakan biaya tetap sehingga menghasilkan harapan revenue dalam menutupi semua biaya tetap dan biaya variabel. Dalam operating leverage perusahaan yang menggunakan biaya tetap dalam proporsi yang tinggi maka dapat dikatakan perusahaan menggunakan operating leverage yang tinggi. Dengan kata lain degree of operating leverage (DOL) untuk perusahaan tersebut tinggi. Apabila perusahaan tidak mempunyai biaya tetap, maka perusahaan akan 
berada dalam posisi yang relatif stabil. Penelitian yang dilakukan oleh Niztiar \& Muharam (2013) dan Abimanyu \& Wirasedana (2015) menemukan bahwa operating leverage berpengaruh positif terhadap struktur modal. Sedangkan penelitian yang dilakukan oleh Yudiandari (2018) serta Dharmadi \& Putri (2018) menemukan bahwa operating leverage berpengaruh negatif terhadap struktur modal.

Faktor ketiga yang mempengaruhi struktur modal adalah ukuran perusahaan. Ukuran perusahaan yang besar akan memaparkan sinyal positif kepada investor atau kreditur untuk menginvestasikan modalnya di perusahaan sehingga menyebabkan penggunaan dana eksternal meningkat (Shubiri, 2010). Karadeniz, et al., (2009), mengungkapkan bahwa perusahaan besar akan cenderung lebih terdiversifikasi dan risiko kebangkrutan akan lebih besar, selain itu kesulitan keuangan akan menjadi lebih rendah. Fleksibilitas inilah yang menyebabkan ukuran perusahaan yang besar lebih gampang memperoleh tambahan dana di pasar modal (Winahyuningsih, et al. 2011). Penelitian yang dilakukan oleh Abimanyu \& Wirasedana (2015) serta Septiani \& Suaryana, 2018) menemukan bahwa ukuran perusahaan berpengaruh positif terhadap struktur modal. Sedangkan penelitian yang dilakukan oleh Nirmala, dkk. (2016) menemukan bahwa ukuran peusahaan berpengaruh negatif terhadap struktur modal.

Faktor keempat yang mempengaruhi struktur modal adalah pertumbuhan penjualan. Menurut Brigham (2010), kestabilan penjualan perusahaan dapat berdampak pada jumlah pinjaman yang dapat diperoleh oleh perusahaan. Semakin baik tingkat penjualan perusahaan maka jumlah pinjaman yang didapatkan akan lebih besar juga. Adanya pertumbuhan penjualan dapat memberikan sinyal yang baik, karena manajemen dinilai memiliki prospek yang bagus dan dapat mempengaruhi struktur modal perusahaan (Oino \& Ukaegbu., 2015). Penelitian yang dilakukan oleh Devita \& Mustanda (2016) dan Watiningsih (2018) menemukan bahwa pertumbuhan penjualan berpengaruh positif terhadap struktur modal. Sedangkan menurut Niztiar \& Muharam (2013) dan Danarwati, et al., (2016) menemukan bahwa pertumbuhan penjualan berpengaruh negatif terhadap struktur modal.

Penelitian ini dilakukan pada perusahaan perbankan yang terdaftar di Bursa Efek Indonesia (BEI), pengambilan objek ini didasari karena siklus hidup bank yang mengandalkan tingkat kepercayaan dari masyarakat karena hampir seluruh modal dan operasional bank berhubungan dengan masyarakat. Penelitian ini merupakan replikasi dari penelitian yang dilakukan oleh Yudiandari (2018). Penelitian ini dilakukan untuk mengetahui konsistensi hasil penelitian terdahulu dengan penelitian sekarang dengan fenomena yang berbeda dan juga periode waktu yang berbeda.

Profitabilitas merupakan kemampuan perusahaan dalam memperoleh laba yang diukur dengan meggunakan persentase yang digunakan untuk menilai sejauh mana perusahaan mampu menghasilkan keuntungan. Salah satu alat ukur yang dapat digunakan untuk mengukur profitabilitas perusahaan adalah Return On Asset (ROA). ROA menunjukkan seberapa banyak laba bersih yang bisa dipoeroleh dari seluruh kekayaan yang dimiliki perusahaan, karena itu dipergunakan angka laba setelah pajak dengan kekayaan perusahaan. Semakin 
besar ROA, berarti semakin efisien penggunaan aktiva perusahaan atau dengan kata lain dengan jumlah aktiva yang sama bisa dihasilkan laba yang lebih bersih, dan sebaliknya. Dalam penelitian Myers \& Majulif (1984) menunjukkan bahwa profitabilitas yang bisa diukur dengan return on asset (ROA) berpengaruh negatif terhadap profitabilitas, dimana perusahaan dengan tingkat pengembalian yang tinggi atas investasi menggunakan utang yang relatif kecil. Semakin tinggi profitabilitas menunjukkan bahwa laba yang diperoleh perusahaan juga tinggi. Peningkatan profitabilitas akan meningkatkan laba ditahan, sesuai dengan pecking order theory yang mempunyai preferensi pendanaan pertama dengan dana internal berupa laba ditahan, sehingga komponen modal sendiri semakin meningkat. Dengan meningkatnya modal sendiri, maka rasio utang menjadi menurun. Hal ini didukung oleh penelitian yang dilakukan oleh Devita \& Mustanda (2016), Bhawa \& Dewi (2015), Yudiandari (2018), Puriandhyni (2017), Andayani \& Suardana (2018), Septiani \& Suaryana (2018) dan Gunadhi \& Putra (2019) membuktikan bahwa profitabilitas berpengaruh negatif terhadap struktur modal. Berdasarkan uraian tersebut, maka hipotesis yang diajukan adalah sebagai berikut.

$\mathrm{H}_{1}$ : Profitabilitas berpengaruh negatif terhadap struktur modal.

Operating Leverage atau degree of operating leverage (DOL) dalam pengertian bisnis mengacu pada penggunaan asset dan sumber dana oleh perusahaan dimana dalam penggunaan asset tersebut harus mengeluarkan biaya tetap. Jika semua biaya bersifat variabel maka memudahkan perusahaan dalam memastikan seberapa besar tingkat perolehan laba. Apabila biaya disuatu perusahaan bersifat tetap, maka perusahaan harus menetapkan target minimum dalam tingkat penjualan tertentu agar perusahaan dapat meningkatkan laba yang maksimal.

Pengaruh operating leverage terhadap struktur modal adalah negative yang artinya semakin tinggi tingkat operating leverage maka akan semakin rendah tingkat utang dan juga struktur modal perusahaan tersebut. Dengan kebijakan mempertahankan struktur modal maka perusahaan bisa meminimalisir akan penggunaan utang yang terkait dengan risiko yang akan dialami oleh perusahaan (Santika \& Sudiyatno, 2011). Hal ini disebabkan karena operating leverage merupakan seberapa besar penggunaan dana pinjaman dalam operasi oleh perusahaan. Perusahaan mengharapkan dengan menggunakan operating leverage maka perubahan penjualan akan mengakibatkan perubahan laba sebelum bunga dan pajak yang lebih besar. Operating leverage akan menguntungkan bagi perusahaan apabila pendapatan setelah dikurangi biaya variabel lebih besar dari biaya tetapnya. Dalam istilah bisnis jika hal-hal lain tetap, tingkat leverage operasi tinggi, maka perubahan yang relatif kecil dalam penjualan akan mengakibatkan perubahan laba operasi yang besar (Brigham, 2010). Dengan demikian semakin rendah biaya tetap yang digunakan maka akan menghasilkan laba yang semakin besar. Dengan laba yang besar maka hal ini akan memungkinkan perusahaan membiayai kebutuhan pendanaanya dengan dana yang dihasilkan secara internal sehingga semakin rendah pula kemungkinan pendanaan dari eksternal (utang).

Hal ini sesuai dengan teori pecking order yang menjelaskan bahwa perusahaan lebih menyukai pendanaan secara internal dibandingkan melakukan 
hutang dan didukung oleh penelitian yang dilakukan oleh Winahyuningsih, dkk. (2011) \& Nugroho (2006). Dengan demikian dapat diprediksi bahwa semakin tinggi operating leverage, maka semakin rendah struktur modal, dimana memiliki makna bahwa peningkatan operating leverage akan berdampak pada menurunnnya struktur modal. Begitu pula sebaliknya penurunan operating leverage akan berdampak pada meningkatnya struktur modal. Hal ini didukung oleh penelitian Pontoh \& Ventje (2013), Yudiandari (2018) dan Dharmadi \& Putri (2018) yang menyatakan bahwa operating leverage berpengaruh negatif terhadap struktur modal. Berdasarkan uraian tersebut, maka hipotesis yang diajukan adalah sebagai berikut.

$\mathrm{H}_{2}$ : Operating leverage berpengaruh negatif terhadap struktur modal.

Besar kecilnya ukuran suatu perusahaan akan berpengaruh terhadap struktur modal, semakin besar perusahaan maka semakin besar pula dana yang dibutuhkan perusahaan untuk melakukan investasinya (Ariyanto, 2014). Oleh karena itu dapat memungkinkan untuk perusahaan besar memiliki utang yang lebih besar dibandingkan perusahaan kecil. Semakin besar ukuran suatu perusahaan, kecenderungan menggunakan modal asing juga semakin besar karena perusahaan besar membutuhkan dana yang besar pula untuk menunjang operasionalnya, dan salah satu alternatif pemenuhannya adalah dengan modal asing apabila modal sendiri tidak mencukupi. Perusahaan yang berukuran besar cenderung lebih fleksibel dalam mengakses sumber dana, sehingga akan meningkatkan utangnya untuk memaksimalkan struktur modal. Menurut tradeoff theory, perusahaan yang besar memiliki risiko kebangkrutan yang lebih kecil dibandingkan perusahaan kecil (Agustina, 2009). Hal ini membuat perusahaan besar memiliki kemudahan dalam memperoleh pinjaman atau utang. Dengan demikian perusahaan besar akan menggunakan utang yang lebih banyak dalam struktur modalnya dibandingkan perusahaan kecil. Atau dengan kata lain, menurut teori ini terdapat hubungan yang positif antara ukuran perusahaan dengan utangnya (Agustina, 2009).

Menurut Trade off theory, ukuran perusahaan yang besar memiliki kesempatan lebih besar untuk masuk ke pasar modal sehingga lebih mudah mendapatkan pinjaman (Titman, 1988). Ukuran perusahaan merupakan salah satu faktor yang dipertimbangkan perusahaan dalam menentukan berapa besar kebijakan atau keputusan pendanaan (struktur modal) dalam memenuhi ukuran atau besarnya aset perusahaan (Rafique, 2011). Hal ini didukung oleh penelitian yang dilakukan oleh Abimanyu \& Wirasedana (2015), Bhawa \& Dewi (2015), Nadzirah, dkk. (2016), dan Septiani \& Suaryana (2018) membuktikan bahwa ukuran perusahaan berpengaruh positif terhadap struktur modal. Berdasarkan uraian tersebut, maka hipotesis yang diajukan adalah sebagai berikut. $\mathrm{H}_{3}$ : Ukuran perusahaan berpengaruh positif terhadap struktur modal.

Menurut Brigham (2010), kestabilan penjualan perusahaan dapat berdampak pada jumlah pinjaman yang dapat diperoleh oleh perusahaan. Semakin baik tingkat penjualan perusahaan maka jumlah pinjaman yang didapat akan lebih besar juga. Menurut Brealy, R.A., Myers \& Marcus (2008) menjelaskan pecking order theory, dimana perusahaan yang penjualannya tumbuh secara besar akan menghasilkan laba yang cukup tinggi sehingga perusahaan lebih cenderung untuk membiayai kegiatan operasi perusahaannya dengan dana 
internal yang dimilikinya yang berasal dari hasil operasinya. Dengan kata lain, semakin tinggi tingkat pertumbuhan penjualan perusahaan, maka semakin rendah ketergantungan perusahaan terhadap modal pinjaman (utang). Adanya pertumbuhan penjualan dapat memberikan sinyal yang baik, karena manajemen dinilai memiliki prospek yang bagus dan dapat mempengaruhi struktur modal perusahaan (Oino, 2015). Hal ini didukung oleh penelitian Devita \& Mustanda (2016), Gunadhi \& Putra (2019) dan Yudiandari (2018) menyatakan bahwa pertumbuhan penjualan berpengaruh positif terhadap struktur modal.

$\mathrm{H}_{4}$ : Pertumbuhan penjualan berpengaruh positif terhadap struktur modal.

\section{METODE PENELITIAN}

Lokasi penelitian ini dilakukan pada perusahaan perbankan yang terdaftar di Bursa Efek Indonesia (BEI) dengan cara mengakses melalui internet, yaitu www.idx.co.id yang merupakan website resmi dari Bursa Efek Indonesia (BEI) dan website perusahaan untuk mendapatkan informasi dan data yang diperlukan. Objek yang diteliti pada penelitian ini adalah struktur modal di perusahaan perbankan yang terdaftar di Bursa Efek Indonesia dengan faktorfaktor yang dapat mempengaruhi struktur modal antara lain profitabilitas, operating leverage, ukuran perusahaan dan pertumbuhan penjualan.

Populasi dalam penelitian ini adalah perusahaan perbankan yang terdaftar di Bursa Efek Indonesia (BEI) dari Tahun 2015-2019. Sampel dalam penelitian ini adalah perusahaan perbankan yang telah dipilih menggunakan metode nonprobability sampling dengan teknik purposive sampling di Bursa Efek Indonesia (BEI) periode 2015-2019.

Penelitian ini menggunakan teknik analisis regresi linier berganda untuk pengolahan dengan bantuan program SPSS for Windows. Teknik ini digunakan untuk mengetahui pengaruh antara lima variabel dalam penelitian, yaitu Profitabilitas, Operating Leverage, Ukuran Perusahaan dan Pertumbuhan Penjualan pada Struktur Modal Perusahaan Perbankan yang terdaftar di Bursa Efek Indonesia periode 2016-2018. Persamaan regresi dalam penelitian ini adalah sebagai berikut.

\begin{tabular}{|c|c|c|c|}
\hline \\
\hline Y & $=$ Struktur Modal & $X_{2}$ & $=$ Operating Leverage \\
\hline a & $=$ Konstanta & $X_{3}$ & $=$ Ukuran Perusahaan \\
\hline$\beta$ & $=$ Koefisien Regresi & $\mathrm{X}_{4}$ & $=$ Pertumbuhan Penjualan \\
\hline$X_{1}$ & $=$ Profitabilitas & $\varepsilon$ & $=$ Error \\
\hline
\end{tabular}

\section{HASIL DAN PEMBAHASAN}

Analisis statistik deskriptif disajikan untuk memberikan informasi umum tentang karakteristik sampel yang berupa nilai tertinggi, nilai terendah, rata-rata, dan deviasi standar. Variabel struktur modal dalam penelitian ini diukur menggunakan rasio Debt to equity ratio. Berdasarkan Tabel 1, nilai rata-rata DER sebesar 4,93 mendekati nilai maksimal sebesar 6,76 artinya kecenderungan ratarata perusahaan memiliki struktur modal yang baik. Nilai standar deviasi atas struktur modal sebesar 1,012 nilai ini lebih kecil dibandingkan nilai rata-rata. Hal ini menunjukkan bahwa sebaran data terkait struktur modal sudah merata atau 
perbedaan data satu dengan data yang lainnya tidak tergolong tinggi. Hasil statistik deskriptif dapat dilihat pada Tabel 1, sebagai berikut.

Tabel 1. Hasil Statistik Deskriptif

\begin{tabular}{llllll}
\hline & $\mathrm{N}$ & Minimum & Maximum & Mean & Std. Deviation \\
\hline DER & 115 & 2,55 & 6,76 & 4,9363 & 1,01255 \\
ROA & 115 & 1,21 & 6,86 & 3,1670 & 1,06886 \\
DOL & 115 & $-2,19$ & 2,45 & 0,3081 & 1,05779 \\
SIZE & 115 & 13,14 & 22,73 & 20,0293 & 2,63580 \\
SALE GROWTH & 115 & $-2,31$ & 2,63 & 0,0043 & 0,88199 \\
Valid N (listwise) & 115 & & & &
\end{tabular}

Sumber: Data Penelitian, 2020

Nilai minimum DER sebesar 2,552 dimiliki oleh BABP pada tahun 2018, hal ini menunjukkan perusahaan belum menerapkan struktur modal dengan maksmimal, sementara nilai maksimumnya adalah sebesar 6,76 dimiliki oleh BBRI pada tahun 2015, hal tersebut menunjukkan bahwa perusahaan tersebut sudah mampu mencapai struktur modal yang maksimal.

Variabel profitabilitas dalam penelitian ini diukur dengan proksi Retrun on Aset. Berdasarkan Tabel 1, nilai rata-rata profitabilitas sebesar 3,167 mendekati nilai maksimum sebesar 6,86. Artinya, ada kecenderungan rata-rata perusahaan sudah memiliki profitabilitas yang baik. Nilai standar deviasi profitabilitas sebesar 1,068 lebih kecil daripada nilai rata-ratanya, artinya sebaran data profitabilitas belum merata atau terdapat perbedaan data satu dengan data yang lainnya yang tergolong tinggi. Nilai profitabilitas terendah sebesar 1,2117 yang dimiliki oleh BACA pada tahun 2017, hal ini menunjukkan bahwa perusahaan cenderung memiliki profitabilitas yang negatif. Nilai tertinggi profitabilitas sebesar 6,86 dimiliki BNII pada tahun 2015, hal tersebut menunjukkan bahwa Bank BNI sudah memiliki profitabilitas yang maksimal.

Variabel operating leverage dalam penelitian ini diukur dengan proksi Current ratio. Berdasarkan Tabel 1, nilai rata-rata operating leverage sebesar 0,3081 mengarah pada nilai maksimum sebesar 2,45. Artinya, ada kecenderungan ratarata perusahaan sudah memiliki operating leverage yang baik. Nilai standar deviasi operating leverage sebesar 1,05 lebih tinggi daripada nilai rata-ratanya, artinya sebaran data operating leverage tidak merata atau perbedaan data satu dengan data yang lainnya tergolong tinggi. Nilai operating leverage terendah sebesar -2,19 yang dimiliki oleh BABP pada tahun 2016, hal ini menunjukkan perusahaan belum menerapkan operating leverage dengan maksmimal. Nilai tertinggi operating leverage sebesar 2,45 dimiliki BKSW pada tahun 2019, hal tersebut menunjukkan bahwa perusahaan Bank BKSW sudah menerapkan operating leverage dengan maksimal.

Variabel ukuran perusahaan dalam penelitian ini diukur menggunakan indikator total aktiva yang ditransformasikan dalam logaritma natural. Berdasarkan Tabel 1, nilai rata-rata ukuran perusahaan sebesar 20,029 mendekati nilai maksimal sebesar 22,73. Artinya, adanya kecenderungan rata-rata perusahaan memiliki ukuran perusahaan yang baik. Nilai deviasi standar ukuran perusahaan sebesar 2,635 lebih rendah dibandingkan dengan nilai rata rata, artinya sebaran data ukuran perusahaan sudah merata atau perbedaan data satu dengan data yang lainnya tidak tergolong tinggi. Nilai ukuran perusahaan 
terendah sebesar 13,14 dimiliki oleh BKSW pada tahun 2019, menunjukkan bahwa BKSW masih tergolong dalam ukuran perusahaan kecil. Nilai tertinggi ukuran perusahaan sebesar 22,73 dimiliki oleh BDMN pada tahun 2016, yang menunjukkan bahwa perusahaan BDMN memiliki ukuran perusahaan yang besar.

Variabel pertumbuhan penjualan dalam penelitian ini diukur dengan membandingkan penjualan pada periode saat ini dikurangi dengan penjualan pada periode sebelumnya dibagi dengan penjualan pada periode sebelumnya dan dikalikan dengan 100 persen. Berdasarkan Tabel 1, nilai rata-rata pertumbuhan penjualan sebesar 0,0043 mendekati nilai maksimum sebesar 2,63. Artinya, ada kecenderungan rata-rata perusahaan memiliki pertumbuhan penjualan yang tinggi. Nilai standar deviasi pertumbuhan penjualan sebesar 0,8819 lebih tinggi daripada nilai rata-ratanya, artinya sebaran data pertumbuhan penjualan tidak merata atau ada perbedaan data satu dengan data yang lainnya yang tergolong tinggi. Nilai pertumbuhan penjualan terendah sebesar $-2,31$ yang dimiliki oleh BABP pada tahun 2019, hal ini menunjukkan perusahaan BABP cenderung memiliki pertumbuhan penjualan yang rendah. Nilai tertinggi pertumbuhan penjualan sebesar 2,63 dimiliki BACA pada tahun 2018, hal tersebut menunjukkan bahwa perusahaan BACA cenderung sudah memiliki pertumbuhan penjualan yang cukup tinggi.

Hipotesis penelitian diuji dengan menggunakan analisis regresi linear berganda. Analisis ini digunakan untuk mengetahui besarnya pengaruh profitabilitas yang diproksikan dengan Retrun on Aset $\left(\mathrm{X}_{1}\right)$, operating leverage yang diproksikan dengan Degree of Operating Leverage (DOL) $\left(X_{3}\right)$. Hasil olahan data dengan SPSS menggunakan model analisis regresi linear berganda dapat dilihat pada Tabel 2, sebagai berikut.

Tabel 2. Hasil Analisis Regresi Linear Berganda

\begin{tabular}{|c|c|c|c|c|c|}
\hline \multirow[t]{2}{*}{ Model } & \multicolumn{2}{|c|}{ Unstandardized Coefficients } & \multicolumn{2}{|c|}{$\begin{array}{l}\text { Standardized } \\
\text { Coefficients }\end{array}$} & \multirow[b]{2}{*}{ Sig. } \\
\hline & B & Std. Error & Beta & $\mathrm{t}$ & \\
\hline (Constant) & .016 & .074 & & .211 & .834 \\
\hline ROA & -.365 & .078 & -.365 & -4.701 & .000 \\
\hline DOL & -.426 & .080 & -.426 & -5.324 & .000 \\
\hline SIZE & .171 & .077 & .177 & 2.222 & .028 \\
\hline SALE GROWTH & .087 & .077 & .087 & 1.130 & .261 \\
\hline
\end{tabular}

Sumber: Data Penelitian, 2020

Dari hasil analisis regresi linear berganda pada Tabel 2, dapat dibuat persamaan sebagai berikut.

$$
Y=0,016-0,365 X 1-0,426 \text { X2 + 0,171 X3 + 0,087 X4 }
$$

Nilai konstanta (a) sebesar 0,016 berarti apabila profitabilitas $\left(X_{1}\right)$, operating leverage $\left(\mathrm{X}_{2}\right)$, ukuran perusahaan $\left(\mathrm{X}_{3}\right)$ dan pertumbuhan penjualan $\left(\mathrm{X}_{4}\right)$ bernilai 0 , maka struktur modal adalah sebesar 0,016 satuan.

Nilai koefisien regresi profitabilitas $\left(\beta_{1}\right)$ sebesar $-0,365$ berarti apabila profitabilitas meningkat sebesar 1 satuan dengan anggapan variabel lainnya konstan, maka struktur modal akan menurun sebesar 0,365 satuan. 
Nilai koefisien regresi operating leverage $\left(\beta_{2}\right)$ sebesar $-0,426$ berarti apabila operating leverage meningkat sebesar 1 satuan dengan anggapan variabel lainnya konstan, maka struktur modal akan menurun sebesar 0,426 satuan.

Nilai koefisien regresi ukuran perusahaan $\left(\beta_{3}\right)$ sebesar 0,171 berarti apabila ukuran perusahaan meningkat sebesar 1 satuan dengan anggapan variabel lainnya konstan, maka struktur modal akan meningkat sebesar 0,171 satuan.

Nilai koefisien regresi pertumbuhan penjualan $\left(\beta_{4}\right)$ sebesar 0,087 berarti apabila pertumbuhan penjualan meningkat sebesar 1 satuan dengan anggapan variabel lainnya konstan, maka struktur modal akan meningkat sebesar 0,087 satuan.

Uji kelayakan model regresi bertujuan untuk mengetahui apakah semua variabel bebas yang diidentifikasi (profitabilitas $\left(X_{1}\right)$, operating leverage $\left(X_{2}\right)$, ukuran perusahaan $\left(X_{3}\right)$ dan pertumbuhan penjualan $\left(X_{4}\right)$ ) tepat digunakan memprediksi Struktur modal.

\section{Tabel 3. Hasil Uji F}

\begin{tabular}{clllll}
\hline Model & Sum Of Squares & Df & Mean Square & F & Sig. \\
\hline 1 Regression & 44,662 & 4 & 11,166 & 17,713 & $0,000^{\mathrm{a}}$ \\
Residual & 69,338 & 110 & 0,630 & & \\
Total & 114,000 & 114 & & & \\
\hline
\end{tabular}

Sumber: Data Penelitian, 2020

Hasil uji F (F test) pada Tabel 3, menunjukkan bahwa nilai $\mathrm{F}$ hitung sebesar 17,713 dengan nilai signifikansi $\mathrm{P}$ value 0,000 yang lebih kecil dari $\alpha=0,05$, ini berarti model yang digunakan pada penelitian ini adalah layak. Hasil ini memberikan makna bahwa seluruh variabel independen yaitu profitabilitas $\left(X_{1}\right)$, operating leverage $\left(\mathrm{X}_{2}\right)$, ukuran perusahaan $\left(\mathrm{X}_{3}\right)$, dan pertumbuhan penjualan $\left(\mathrm{X}_{4}\right)$ tepat memprediksi atau menjelaskan fenomena Struktur modal. Dengan kata lain, profitabilitas $\left(X_{1}\right)$, operating leverage $\left(X_{2}\right)$, ukuran perusahaan $\left(X_{3}\right)$ dan pertumbuhan penjualan $\left(\mathrm{X}_{4}\right)$ secara simultan berpengaruh signifikan pada struktur modal.

Uji koefisien determinasi pada intinya bertujuan untuk mengetahui dan mengukur kemampuan model dalam menerangkan variasi variabel independen. Nilai koefisien determinisi dapat dilihat pada nilai $\mathrm{R}^{2}$ dalam model regresi. Peneliti menggunakan nilai $\mathrm{R}^{2}$ pada saat mengevaluasi yang mana model regresi terbaik. Hasil uji koefisien determinasi dapat dilihat pada Tabel 4, berikut.

Tabel 4. Hasil Uji Koefisien Determinasi

\begin{tabular}{lllll}
\hline Model & $\mathrm{R}$ & $\mathrm{R}$ Square & Adjusted R Square & Std. Error of the Estimate \\
\hline 1 & $0,626^{\mathrm{a}}$ & 0,392 & 0,370 & 0,79394240 \\
\hline
\end{tabular}

Sumber: Data Penelitian, 2020

Hasil uji memberikan hasil dimana diperoleh besarnya nilai $\mathrm{R}^{2}$ adalah 0,506 . Ini berarti variasi struktur modal dapat dipengaruhi secara signifikan oleh variabel profitabilitas $\left(X_{1}\right)$, operating leverage $\left(X_{2}\right)$, ukuran perusahaan $\left(X_{3}\right)$ dan pertumbuhan penjualan $\left(X_{4}\right)$ sebesar 39,2 persen sedangkan sisanya sebesar 60,8 persen dijelaskan oleh faktor-faktor lain yang tidak dijelaskan dalam model penelitian

Hipotesis pertama menyatakan bahwa profitabilitas berpengaruh negatif pada struktur modal. Berdasarkan hasil uji $t$ analisis regresi linier berganda pada Tabel 2, menunjukkan koefisien regresi profitabilitas adalah -0,365 dengan 
tingkat signifikansi sebesar 0,000 yang kurang dari 0,05. Artinya, profitabilitas berpengaruh negatif dan signfikan pada struktur modal. Sehingga, dapat disimpulkan bahwa hipotesis pertama diterima.

Hasil penelitian ini menunjukkan bahwa profitabilitas yang meningkat akan menurunkan struktur modal perusahaan. Temuan ini sesuai dengan teori pecking order yang menjelaskan bahwa semakin tinggi profitabilitas suatu perusahaan, maka akan cenderung tidak menggunakan hutang untuk membiayai investasinya. Berdasarkan teori pecking order tersebut perusahaan dengan tingkat laba tinggi mempunyai kekuatan dana internal yang lebih besar serta mendorong penggunaan dana internal lebih dahulu untuk keperluan pembiayaan investasi sehingga tingkat hutang atau pendanaan dapat ditekan yang kedepannya dapat memperkecil resiko kegagalan pemenuhan kewajiban seperti biaya bunga dan kondisi bangkrut. Hal ini mengindikasikan bahwa perusahaan yang profitable cenderung menyukai pembiayaan yang berasal dari internal perusahaan dibandingkan pendanaan yang berasal dari hutang.

Temuan ini sejalan dengan penelitian Devita \& Mustanda, (2016) menyatakan bahwa profitabilitas berpengaruh negatif terhadap struktur modal, karena semakin besar profitabilitas yang didapatkan oleh perusahaan maka akan menurunkan struktur modal perusahaan. Hasil penelitian ini juga mendukung temuan penelitian Bhawa \& Dewi (2015), Yudiandari (2018), Puriandhyni (2017), Andayani \& Suardana (2018), Septiani \& Suaryana (2018) dan Gunadhi \& Putra (2019) yang menemukan hasil bahwa profitabilitas berpengaruh negatif dan signifikan terhadap struktur modal. Kondisi ini menunjukkan bahwa semakin tinggi besarnya profitabilitas yang dihasilkan, maka semakin rendah struktur modalnya. Keputusan manajemen menurunkan penggunaan hutang ketika profitabilitas yang dihasilkan tinggi, situasi ini sesuai dengan prinsip pecking order theory dimana manajemen memilih pembiayaan dari dalam untuk menambah kebutuhan modalnya. Penggunaan hutang hanya akan dilakukan jika pembiayaan dari dalam tidak cukup untuk menutup kebutuhan modal yang diperlukan.

Hipotesis kedua menyatakan bahwa operating leverage berpengaruh negatif pada struktur modal. Berdasarkan hasil uji $t$ analisis regresi linier berganda pada Tabel 2, menunjukkan koefisien regresi operating leverage adalah -0,426 dengan tingkat signifikansi sebesar 0,000 yang kurang dari 0,05. Artinya, operating leverage berpengaruh negatif dan signfikan pada struktur modal. Sehingga, dapat disimpulkan bahwa hipotesis kedua diterima.

Hasil penelitian ini menunjukkan bahwa semakin tinggi tingkat operating leverage maka akan semakin rendah tingkat utang dan juga struktur modal perusahaan tersebut. Dengan kebijakan mempertahankan struktur modal maka perusahaan bisa meminimalisir akan penggunaan utang yang terkait dengan risiko yang akan dialami oleh perusahaan. Hasil penelitian ini sesuai dengan pecking order theory yang menjelaskan bahwa perusahaan lebih menyukai pendanaan secara internal dibandingkan melakukan hutang. Hal ini disebabkan karena operating leverage merupakan seberapa besar penggunaan dana pinjaman dalam operasi oleh perusahaan. Perusahaan mengharapkan dengan menggunakan operating leverage maka perubahan penjualan akan mengakibatkan perubahan laba sebelum bunga dan pajak yang lebih besar. Operating leverage 
akan menguntungkan bagi perusahaan apabila pendapatan setelah dikurangi biaya variabel lebih besar dari biaya tetapnya. Dalam istilah bisnis jika hal-hal lain tetap, tingkat leverage operasi tinggi, maka perubahan yang relatif kecil dalam penjualan akan mengakibatkan perubahan laba operasi yang besar (Brigham, 2010). Dengan demikian semakin rendah biaya tetap yang digunakan maka akan menghasilkan laba yang semakin besar. Dengan laba yang besar maka hal ini akan memungkinkan perusahaan membiayai kebutuhan pendanaanya dengan dana yang dihasilkan secara internal sehingga semakin rendah pula kemungkinan pendanaan dari eksternal (utang).

Hasil penelitian ini sejalan dengan temuan penelitian Pontoh \& Ventje (2013) yang memperoleh hasil bahwa terdapat pengaruh yang negatif signifikan antara operating leverage terhadap struktur modal. Hasil penelitian ini juga mendukung temuan penelitian Yudiandari (2018) dan Dharmadi \& Putri (2018) yang menyatakan bahwa operating leverage berpengaruh negatif terhadap struktur modal.

Hipotesis ketiga menyatakan bahwa ukuran perusahaan berpengaruh positif dan signifikan pada struktur modal. Berdasarkan hasil uji $t$ analisis regresi linier berganda pada Tabel 2, memperoleh nilai koefisien regresi ukuran perusahaan sebesar 0,171 dengan tingkat signifikansi sebesar 0,028 yang kurang dari 0,05. Artinya, ukuran perusahaan berpengaruh positif dan signifikan pada struktur modal. Sehingga, dapat disimpulkan bahwa hipotesis ketiga diterima.

Hasil penelitian ini menunjukkan bahwa besar kecilnya ukuran perusahaan mampu memengaruhi kenaikan struktur modal yang diproksikan dengan Debt to equity ratio. Hal ini menunjukkan ukuran perusahaan yang besar akan mempengaruhi kelangsungan hidup perusahaan maupun lancarnya kegiatan operasional perusahaan. Dengan demikian ukuran perusahaan yang besar akan meningkatkan minat investor maupun kreditor dalam menanamkan dananya ke perusahaan.

Hasil penelitian ini sesuai dengan trade-off theory. Menurut Trade off theory, ukuran perusahaan yang besar memiliki kesempatan lebih besar untuk masuk ke pasar modal sehingga lebih mudah mendapatkan pinjaman. Besar kecilnya ukuran suatu perusahaan akan berpengaruh terhadap struktur modal, semakin besar perusahaan maka semakin besar pula dana yang dibutuhkan perusahaan untuk melakukan investasinya (Ariyanto, 2014). Menurut trade-off theory, perusahaan yang besar memiliki risiko kebangkrutan yang lebih kecil dibandingkan perusahaan kecil (Agustina, 2009). Hal ini membuat perusahaan besar memiliki kemudahan dalam memperoleh pinjaman atau utang. Dengan demikian perusahaan besar akan menggunakan utang yang lebih banyak dalam struktur modalnya dibandingkan perusahaan kecil. Atau dengan kata lain, menurut teori ini terdapat hubungan yang positif antara ukuran perusahaan dengan utangnya (Agustina, 2009).

Hasil penelitian ini sesuai dengan hasil penelitian yang ditemukan oleh Rafique (2011) yang menyatakan bahwa ukuran perusahaan berpengaruh positif dan signifikan terhadap struktur modal. Ukuran perusahaan merupakan salah satu faktor yang dipertimbangkan perusahaan dalam menentukan berapa besar kebijakan atau keputusan pendanaan (struktur modal) dalam memenuhi ukuran atau besarnya aset perusahaan. Hasil penelitian ini juga mendukung temuan 
penelitian Abimanyu \& Wirasedana (2015), Bhawa \& Dewi (2015), Nadzirah, dkk. (2016), Puriandhyni (2017) dan Septiani \& Suaryana (2018) membuktikan bahwa ukuran perusahaan berpengaruh positif terhadap struktur modal.

Hipotesis keempat menyatakan bahwa pertumbuhan penjualan tidak berpengaruh signifikan pada struktur modal. Berdasarkan hasil uji $t$ analisis regresi linier berganda pada Tabel 2, menunjukkan koefisien regresi pertumbuhan penjualan adalah 0,087 dengan tingkat signifikansi sebesar 0,261 yang lebih dari 0,05. Artinya, pertumbuhan penjualan tidak berpengaruh signfikan pada struktur modal. Sehingga, dapat disimpulkan bahwa hipotesis keempat ditolak.

Pertumbuhan penjualan tidak berpengaruh signfikan pada struktur modal, hal ini disebabkan karena pertumbuhan penjualan perusahaan perbankan yang terdaftar di BEI peridoe 2015-2019 tidak mengalami kestabilan dari tahun ke tahun. Keuntungan perusahaan dari tahun 2015-2019 mengalami fluktuasi yang berbeda-beda tiap perusahaan. Beberapa perusahaan memiliki gap yang jauh antar tahun sehingga menyebabkan terjadinya perbedaan data ekstrem. Hal ini memperbesar ketidak stabilan penjualan pada perusahaan perbankan yang diteliti dalam penelitian ini. Akibatnya struktur modal sulit diprediksi melalui perubahan pertumbuhan penjualan. Sejalan dengan pendapat Kurniawan (2013), stabilitas penjualan akan mempengaruhi stabilitas pendapatan yang pada akhirnya dapat memperoleh dana internal lebih besar dan mampu membayar biaya utang. Stabilitas penjualan akan mempengaruhi stabilitas pendapatan, karena pertumbuhan penjualan tidak stabil dari tahun ke tahun maka bisa dikatakan pendapatan juga tidak stabil, laba tidak stabil. Hal ini berakibat sulit memprediksi struktur modal dari pertumbuhan penjualan, oleh karena itu perusahaan perbankan tidak mempertimbangkan pertumbuhan penjualan sebagai faktor yang mempengaruhi struktur modal.

Temuan ini sejalan dengan penelitian yang dilakukan oleh Rudi \& Kiswanto (2013) yang menyatakan bahwa pertumbuhan penjualan tidak berpengaruh secara signifikan terhadap Struktur Modal Perusahaan. Penelitian ini juga mendukung hasil temuan Rizky, dkk. (2016) yang menyatakan bahwa pertumbuhan penjualan tidak berpengaruh signifikan terhadap struktur modal. Hal ini disebabkan karena perusahaan yang memiliki pertumbuhan penjualan yang tinggi, maka perusahaan memiliki potensi mendapatkan laba yang besar, dan laba ditahan akan ikut meningkat. Sehingga perusahaan akan cenderung menggunakan dana internal untuk memenuhi kebutuhan modalnya.

\section{SIMPULAN}

Implikasi teoritis hasil penelitian ini adalah diketahuinya profitabilitas $\left(X_{1}\right)$, operating leverage $\left(X_{2}\right)$, ukuran perusahaan $\left(X_{3}\right)$ dan pertumbuhan penjualan $\left(X_{4}\right)$ secara simultan berpengaruh pada struktur modal yang mampu untuk membuktikan secara empiris teori yang digunakan pada penelitian ini yaitu teori pecking order dan teori trade off. Implikasi teoritis hasil penelitian ini juga dapat memberikan rujukan tambahan bagi penelitian selanjutnya yang membahas mengenai profitabilitas $\left(X_{1}\right)$, operating leverage $\left(X_{2}\right)$, ukuran perusahaan $\left(X_{3}\right)$ dan pertumbuhan penjualan $\left(\mathrm{X}_{4}\right)$ terhadap struktur modal. Implikasi praktis hasil penelitian ini adalah diketahuinya profitabilitas $\left(X_{1}\right)$, operating leverage $\left(X_{2}\right)$, 
ukuran perusahaan $\left(X_{3}\right)$ dan pertumbuhan penjualan $\left(X_{4}\right)$ berpengaruh signifikan pada struktur modal, maka manajemen perusahaan dapat memperhatikan variabel-variabel tersebut dalam mengambil kebijakan berkaitan dengan struktur modal perusahaan.

\section{REFERENSI}

Abimanyu, M. A., \& Wirasedana, W. P. (2015). Pengaruh Ukuran Perusahaan, Variabilitas Pendapatan Dan Operating Leverage Pada Struktur Modal Industri Perbankan. E-Jurnal Akuntansi, 11(3), 848-862.

Agustina, N. (2009). Analisis Pengaruh Faktor Profitabilitas, Tingkat Pertumbuhan, Tingkat Pajak, Struktur Asset, Risiko, Dan Ukuran Bank Terhadap Struktur Modal Bank Di Indonesia Pada Periode Penelitian 2003 Hingga 2007. Skripsi. Universitas Indonesia.

Andayani, I. A. K. T., \& Suardana, K. A. (2018). Pengaruh Profitabilitas, Likuiditas, Pertumbuhan Penjualan, dan Struktur Aktiva Pada Struktur Modal. E-Jurnal Akuntansi, 370. https:// doi.org/10.24843/eja.2018.v24.i01.p14

Ariyanto, T. (2014). Pengaruh Struktur Kepemilikan Terhadap Struktur Modal Perusahaan. Jurnal Manajemen, (1), 64-71.

Brealy, R.A., Myers, S. ., \& Marcus, A. . (2008). Fundamenals of Corporate Finance. (Sixth Edit). Mcgraw Hill.

Brigham, E. F. dan J. F. H. (2010). Dasar-Dasar Manajemen Keuangan (Buku 1 Edi). Salemba Empat.

Danarwati, M., Raharjo, K., \& Abrar. (2016). Pengaruh Ukuran Perusahaan, Leverage, Likuiditas, Profitabilitas Terhadap Struktur Modal. Jurnal Akuntansi, 44, 160-197. https://doi.org/10.21608/aafu.2016.14660

Devita Angelina, K., \& Mustanda, I. (2016). Pengaruh Ukuran Perusahaan, Pertumbuhan Penjualan Dan Profitabilitas Pada Struktur Modal Perusahaan. E-Jurnal Manajemen Universitas Udayana, 5(3), 245337.

Dharmadi, I. K. Y., \& Dwija Putri, I. G. A. M. A. (2018). Pengaruh Struktur Aset, Profitabilitas, Operating Leverage Dan Likuiditas Terhadap Struktur Modal Perusahaan Consumer Goods di BEI. E-Jurnal Akuntansi, 24, 1858. https:// doi.org/10.24843/eja.2018.v24.i03.p08

Gunadhi, G. B. D., \& Putra, I. M. P. D. (2019). Pengaruh Profitabilitas, Struktur Aset, Likuiditas, Dan Pertumbuhan Penjualan Terhadap Struktur Modal Perusahaan Makanan Dan Minuman. E-Jurnal Akuntansi, 28, 641. https:// doi.org/10.24843/eja.2019.v28.i01.p25

Karadeniz, E., Kandir, S. Y., Balcilar, M., \& Onal, Y. B. (2009). Determinants of capital structure: Evidence from Turkish lodging companies. International Journal of Contemporary Hospitality Management, 21(5), 594-609. https:/ / doi.org/10.1108/09596110910967827

Kasmir. (2010). Analisis Laporan Keuangan. PT Raja Grafindo Persada.

Kurniawan, G. D. (2013). Pengaruh Likuiditas, Ukuran Perusahaan, Pertumbuhan Penjualan Dan Profitabilitas Terhadap Struktur Modal Pada Perusahaan Ritel Di Bei. Jurnal Profita, 5(1), 15-31. 
Myers, S. ., \& Majulif, N. (1984). Corporate Financing and Investment Decisions When Firms Have Information That Investors Do Not Have. Journal of Economics, 13(2), 187-221.

Nadzirah, Yudiaatmaja, F., \& Cipta, W. (2016). Pengaruh Ukuran Perusahaan, Struktur Aktiva dan Profitabilitas terhadap Struktur Modal. E-Journal Bisma Universitas Pendidikan Ganesha, 4(1), 1-13.

Nirmala, A., Moeljadi, M., \& Andarwati, A. (2016). Pengaruh Ukuran Perusahaan, Profitabilitas, Pertumbuhan Penjualan dan Kepemilikan Manajerial terhadap Struktur Modal dan Nilai Perusahaan Manufaktur di Indonesia (Perspektif Pecking Order Theory). Jurnal Aplikasi Manajemen, 14(3), 557-566. https:// doi.org/10.18202/jam23026332.14.3.16

Niztiar, G., \& Muharam, H. (2013). Analisis Faktor-Faktor Yang Mempengaruhi Pertambangan Yang Terdaftar Di Bursa Efek Indonesia Periode 2008-2011 ). 2, 18.

Nugroho, A. S. (2006). Analisis Faktor-Faktor Yang Mempengaruhi Struktur Modal Perusaha Properti Yang Go-Public Di Bursa Efek Jakarta Untuk Periode Tahun 1994 - 2004. Tesis Universitas Diponegoro, 1-87.

Oino, I. \& U. (2015). The impact of profitability on capital structure and speed of adjustment: An empirical examination of selected firm in Nigerian Stock Exchange. Research in International Business and Finance (35th ed.).

Pontoh, W., \& Ventje, I. (2013). Determinant Capital Structure and Profitability Impact (Study of Listed Company in Indonesian Stock Exchange). Reasearch Journal of Finance and Accounting, 4((15)), 43-49.

Puriandhyni, D. (2017). Pengaruh Profitabilitas, Likuiditas dan Ukuran Perusahaan Terhadap Struktur Modal. Jurnal Ekonomi.

Putri, S. M. . (2014). Pengaruh Dividend Payout Ratio (DPR), Debt Equity Ratio (DER), Return On Asset (ROA), dan Size perusahaan terhadap Nilai Perusahaan pada Perusahaan Manufaktur yang Terdaftar di Bursa Efek Indonesia (BEI) Periode 2009-2012. E-Journal Fakultas Ekonomi Universitas Maritim Raja Ali Haji.

Rafique, M. (2011). Effect of Profitability \& Financial Leverage On Capital Structure: A Case of Pakistan's Automobile Industry. Economic and Finance Review, 1((4)), 50-58.

Rizky, M., Khairunnisa, \& Nurbaiti, A. (2016). Pengaruh Struktur Aktiva, Profitabilitas, dan Pertumbuhan Penjualan Terhadap Struktur Modal (Studi pada Perusahaan Telekomunikasi yang Terdaftar di Bursa Efek Indonesia (BEI) Tahun 2011-2015). E-Proceeding of Management, 3(3), 3249-3256.

Rudi Pradana, H., \& Kiswanto, F. (2013). Pengaruh Risiko Bisnis, Struktur Aset, Ukuran Dan Pertumbuhan Penjualan Terhadap Struktur Modal. Accounting Analysis Journal, 2(4), 423-429. https:// doi.org/10.15294/aaj.v2i4.4168

Salyo, V. (1995). Analisis Beberapa Faktor yang Berpengaruh Terhadap Struktur Finansia Pada Industri di Surabaya.

Santika, R. B., \& Sudiyatno, B. (2011). Determinant of Capital Structure on The Manufacturing Company Capital In Indonesia Stock Exchange. Dinamika Keuangan Dan Perbankan, 3(2), 172-182.

Septiani, N. P. N., \& Suaryana, I. G. N. A. (2018). Pengaruh Profitabilitas, Ukuran Perusahaan, Struktur Aset, Risiko Bisnis dan Likuiditas pada Struktur 


\section{Modal. E-Jurnal Akuntansi,}

https:// doi.org/10.24843/eja.2018.v22.i03.p02

Shubiri, F. A.-. (2010). An-Najah Univ. J. of Res. (Humanities), Vol. 24(8), 2010. Journal of Res. (Humanities), 24(8).

Titman, S. dan R. W. (1988). The Determinants of Capital Structure Choice. The Journal of Finance, 43 (1), 1-19.

Van Home, j. . dan W. (2007). Fundamentals of Financial Management, Prinsipprinsip Manajemen Keuangan (Buku 1 Edi). Salemba Empat.

Watiningsih, F. (2018). Pengaruh Profitabilitas, Ukuran Perusahaan, Tangibility, Dan Pertumbuhan Terhadap Struktur Modal Pada Perbankan Yang Terdaftar Di Bei Periode 2008-2016. Jurnal SEKURITAS (Saham, Ekonomi, Keuangan Dan Investasi), 1(4), 92-105. https:// doi.org/10.32493/skt.v1i4.1382

Winahyuningsih, P., Sumekar, K., \& Prasetyo, H. (2011). Analisis Faktor-Faktor Yang Mempengaruhi Struktur Modal Pada Perusahaan Manufaktur Yang Go Public Di Bursa Efek Indonesia. 1-17.

Yudiandari, C. I. D. (2018). Pengaruh Profitabilitas, Operating Leverage, Ukuran Perusahaan dan Pertumbuhan Penjualan pada Struktur Modal. E-Jurnal Akuntansi Universitas Udayana, 22(1), 408-437. https:// doi.org/10.24843/EJA.2018.v22.i01.p16 